\title{
\begin{tabular}{|c|c|}
\hline JURNAL EKONOMI DAN MANAJEMEN \\
P-ISSN: 2598-9022/ E-ISSN: 2598-9618 \\
Available at: http://e-journal.unipma.ac.id/index.php/capital
\end{tabular}
}

\section{Motivasi dan Tantangan Menjadi Wirausaha (Studi Kuantitatif pada Mahasiswa UNIPMA)}

\author{
Septyana Luckyta Sari \\ Fakultas Ekonomi dan Bisnis, Universitas PGRI Madiun \\ email: luckytasari@unipma.ac.id
}

\begin{abstract}
Data Badan Pusat Statistik for August 2020 recorded that 138.22 million Indonesians are in the workforce, the unemployment rate reached $7.07 \%$. The high number of unemployed hinders economic growth. So Indonesia must increase the number of entrepreneurs. This problem encourages the government to cooperate with Kementerian Riset dan Perguruan Tinggi to apply entrepreneurship courses in education curriculum. The program and its mechanisms are expected to encourage economic growth in Indonesia and create many jobs. The research objective was to determine the entrepreneurial perceptions of sixth semester management students of Universitas PGRI Madiun. This research is supported by various factors such as motivators, challenges and government support to start and maintain new businesses. This study also tries to see whether there are differences between gender, educational background, parents, and work experience as demographic factors with one's entrepreneurial intentions. This research uses quantitative methods. Data collection using google form link questionnaire which was distributed to 337 students through class leaders. The data analysis used was descriptive statistics. The results of this study indicate that students of Universitas PGRI Madiun have a high enough intention to become entrepreneurs. Their greatest motivation is to increase income opportunities. Meanwhile, what is considered the biggest challenge in becoming an entrepreneur is funding. So, government support that is deemed urgently needed is to provide financial assistance.
\end{abstract}

Keywords: Entrepreneurship, Students, Motivation, Challenges, Government Support

\begin{abstract}
Abstrak
Data Badan Pusat Statistik bulan Agustus 2020 tercatat 138,22 juta penduduk Indonesia merupakan angkatan kerja, angka penganggurannya mencapai $7,07 \%$. Jumlah pengangguran yang tinggi menghambat pertumbuhan perekonomian. Maka Indonesia harus memperbanyak jumlah wirausaha. Permasalahan ini mendorong pemerintah bekerja sama dengan Kementerian Riset dan Perguruan Tinggi untuk menerapkan mata kuliah Kewirausahaan dalam kurikulum pendidikan. Program dan mekanismenya diharapkan mendorong pertumbuhan ekonomi Indonesia dan tercipta banyak lapangan kerja. Tujuan penelitian adalah mengetahui persepsi kewirausahaan mahasiswa manajemen Universitas PGRI Madiun semester enam. Penelitian ini didukung dengan berbagai macam faktor seperti motivator, tantangan serta dukungan pemerintah untuk memulai dan mempertahankan usaha baru. Penelitian ini juga mencoba melihat apakah ada perbedaan antara gender, latar belakang pendidikan, orang tua, dan pengalaman bekerja sebagai faktor demografis dengan niat berwirausaha seseorang. Penelitian ini menggunakan metode kuantitatif. Pengumpulan data dengan kuesioner link google form yang dibagikan kepada 337 mahasiswa semester enam melalui ketua kelas. Analisis data yang digunakan adalah statistik deskriptif. Hasil penelitian ini menyebutkan bahwa mahasiswa Universitas PGRI Madiun memiliki niat yang cukup tinggi untuk menjadi wirausaha. Motivasi terbesarnya adalah untuk menaikkan peluang pendapatan. Sementara yang dianggap tantangan terbesar untuk menjadi wirausaha adalah pendanaan. Maka sejalan dengan dukungan pemerintah yang sangat dibutuhkan adalah menyediakan asistensi pendanaan.
\end{abstract}

Kata Kunci: Wirausaha, Mahasiswa, Motivasi, Tantangan, Dukungan Pemerintah 


\section{A. PENDAHULUAN}

Lulus dan berhasil menyelesaikan studi di bangku perkuliahan adalah impian setiap mahasiswa. Tantangan yang paling nyata adalah mencari lapangan pekerjaan. Menurut data dari Badan Pusat Statistik, pada bulan Agustus 2018 hingga Agustus 2020 menunjukan bahwa tingkat pengangguran di Indonesia masih cukup tinggi, dan selalu meningkat setiap tahunnya. Data terakhir pada bulan Agustus 2020 tercatat bahwa dari 138,22 juta penduduk di Indonesia yang masuk dalam angkatan kerja, angka penganggurannya mencapai 9,77 juta orang atau $7,07 \%$ meningkat $1,84 \%$ dari tahun sebelumnya. Banyaknya fresh graduate yang memiliki mindset untuk menjadi budak corporate setelah lulus dari perguruan tinggi menjadi salah satu kendala dan faktor yang sangat berpengaruh, karena tingginya persaingan dan semakin sempitnya lapangan kerja. Jumlah pengangguran yang tinggi ini juga menghambat pertumbuhan perekonomian Indonesia. Jika Indonesia ingin menjadi negara maju salah satu cara yang harus dilakukan adalah memperbanyak jumlah wirausaha yang mau mendirikan usaha secara mandiri, aktif, dan siap berkembang. Oleh sebab itu, kewirausahaan telah menjadi agenda utama di Indonesia, dengan pengenalan program dan mekanisme kewirausahaan yang diperuntukkan bagi pengembangan dan pengelolaan kegiatan kewirausahaan.

Permasalahan ini mendorong pemerintah bekerja sama dengan Kementerian Riset dan Perguruan Tinggi untuk menerapkan mata kuliah Kewirausahaan kedalam kurikulum pendidikan. Program dan mekanisme tersebut diharapkan dapat mendorong pertumbuhan ekonomi Indonesia yang pada gilirannya akan menciptakan lebih banyak lapangan kerja. Universitas PGRI Madiun menjadi salah satu intitusi pendidikan yang juga menerapkan kurikulum tersebut, dimana mata kuliah kewirausahaan dijadikan sebagai mata kuliah wajib yang harus ditempuh mahasiswa semester enam. Universitas PGRI Madiun juga merupakan salah satu kampus besar di Kota Madiun dimana khususnya untuk program pendidikan Manajemen, mahasiswa semester enam yang sudah menempuh mata kuliah kewirausahaan cukup banyak dan berasal dari berbagai latar belakang, yaitu 337 mahasiswa. Ilmu kewirausahaan berperan penting dalam menumbuhkan minat berwirausaha yang nantinya ditujukan untuk memberikan pengalaman praktis kepada para mahasiswa manajemen di Universitas PGRI Madiun dari para pelaku usaha sebelumnya, baik skala besar, menengah, maupun kecil. Dengan 
adanya mata kuliah kewirausahaan diharapkan akan menambah wawasan mahasiswa terhadap ilmu kewirausahaan dan serta memotivasi mahasiswa untuk terlibat langsung dalam kegiatan kewirausahaan dan menjadi wirausahawan muda yang tangguh. Mata kuliah kewirausahaan juga dapat dijadikan sebagai media untuk mengetahui kendala yang sering dihadapi ketika memulai sebuah usaha.

Kiat Universitas PGRI Madiun melahirkan wirausahawan-wirausahawan muda yang diharapkan nantinya akan membantu menurunkan jumlah pengangguran di Indonesia, juga didukung oleh kegiatan pemerintah setempat. Menurut Walikota Madiun Maidi (2020) pada Forum Pemberdayaan UMKM mengatakan bahwa Kota Madiun kedepannya menargetkan sebagai kota penggerak dan pemain utama kegiatan ekonomi dengan strategi utama adalah pemberdayaan UMKM. Pemerintah Kota Madiun telah menganggarkan sejumlah dana permodalan dengan nominal yang cukup besar yaitu Rp 12 Miliar pada tahun 2020 untuk program kredit murah sebagai salah satu cara untuk penguatan ekonomi sektor Usaha Mikro Kecil dan Menengah. Selain itu, pemerintah Kota Madiun juga memberikan Pembinaan dan Pemasaran UMKM dengan menggandeng Badan Ekonomi Kreatif (Bekraf) RI.

Peningkatan minat berwirausaha mahasiswa manajemen Universitas PGRI Madiun terhadap dunia kewirausahaan juga semakin tinggi. Hal ini dibuktikan banyaknya mahasiswa yang memiliki usaha sendiri disamping kegiatannya selama kuliah. Usaha yang mereka jalani mayoritas usaha yang dijalankan dengan biaya mandiri, seperti: usaha butik, salon, desain, kuliner, aksesoris, laundry dan sebagainya, baik secara online maupun offline. Melihat pesatnya peningkatan minat berwirausaha di kalangan mahasiswa manajemen Universitas PGRI Madiun, maka terkait dengan latar belakang tersebut, sangat diperlukan penelitian mengenai pengaruh mata kuliah kewirausahaan terhadap minat mahasiswa menjadi wirausaha pada Universitas PGRI Madiun. Tujuan utama dari penelitian ini adalah untuk mengetahui persepsi mahasiswa manajemen Universitas PGRI Madiun semester enam terhadap kewirausahaan. Penelitian ini didukung dengan berbagai macam faktor seperti motivator, tantangan, serta dukungan pemerintah di balik memulai dan mempertahankan usaha baru. Penelitian ini juga mencoba untuk melihat apakah ada perbedaan antara gender, latar belakang pendidikan, orang tua, dan pengalaman bekerja sebagai faktor demografis dengan niat berwirausaha seseorang. 


\section{B. TINJAUAN PUSTAKA}

\section{Faktor Motivasi}

Penelitian Kao (1995), Koh (1996), Zhuplev, dkk. (1998), Shane, et.al. (2003), Kuratko dan Hodgetts (2007), Liang dan Dunn (2007) banyak berfokus pada karakteristik dan aspek motivasi wirausaha. Motivasi yang tepat sangat dibutuhkan oleh calon wirausaha atau wirausaha yang baru memulai bisnisnya. Motivasi dalam hal ini dapat dikategorikan menjadi dua, yaitu motivasi intrinsik dan motivasi ekstrinsik. Seseorang yang termotivasi akan tergerak untuk melakukan sesuatu. Maka, orang yang memiliki hasrat tinggi dan antusias mencapai tujuan dianggap termotivasi. Sementara yang tidak memiiki dorongan atau inspirasi untuk mencapai tujuan dianggap tidak termotivasi (Ryan dan Deci, 2000).

Motivasi intrinsik mencerminkan keinginan seseorang untuk melakukan sesuatu dengan dorongan dari dalam diri karena senang saat melakukaannya. Motivasi ekstrinsik mencerminkan keinginan seseorang untuk melakukan sesuatu karena imbalan eksternal, misalnya uang atau penghargaan. Menurut Simola (2011) individu yang termotivasi secara intrinsik memiliki kesenangan dan semangat yang lebih besar untuk memulai bisnis dibanding dengan individu yang hanya termotivasi secara ekstrinsik.

Penelitian yang dilakukan Moy et. al (2001) tentang motivasi mahasiswa Thailand dan Hongkong untuk memulai usaha baru menunjukkan bahwa secara umum motivasi berupa penghargaan intrinsik, penghargaan ekstrinsik, otonomi, keamanan keluarga, dan manajemen perubahan membuat seseorang memutuskan untuk memilih berwirausaha. Temuan serupa juga didukung oleh penelitian Kuratko dan Hodgetts (2007) tentang tujuan wirausaha dalam mempertahankan perkembangan usahanya.

\section{Tantangan/Rintangan}

Proses wajar bagi wirausaha untuk menghadapi tantangan selama tahap awal memulai usaha baru. Maka, berpikiran terbuka menjadi suatu modal dalam menghadapi tantangan. Young dan Welsch (1993) mengidentifikasi bahwa wirausaha memiliki beberapa kendala antara lain kurangnya bantuan keuangan, kurang informasi tentang berbagai aspek bisnis, perpajakan dan inflasi yang tinggi. Pernyataan tersebut juga didukung oleh Kozan et. al (2006) yang menyatakan bahwa kesulitan pembiayaan menghambat peningkatan teknologi dan agregasi sumber daya bagi wirausaha di Turki. 
Sebuah penelitian oleh Moy, et. al (2001) menyarankan bahwa di kalangan mahasiswa, faktor eksogen dan endogen merupakan tantangan utama yang dihadapi saat memulai dan mempertahankan bisnis diantaranya adalah biaya tenaga kerja tinggi, suku bunga tinggi, aturan pemerintah yang ketat, dan kurangnya pengalaman manajerial, kurangnya pengetahuan teknis, dan risiko berlebihan. Tantangan serupa juga ditemukan dalam penelitian Zhuplev, et. al (1998) tentang motivasi dan hambatan pemilik usaha kecil Rusia dan Amerika yang mengungkapkan tingginya pajak, kebencian terhadap peraturan pemerintah, dan modal awal menjadi kendala utama bagi pemilik usaha di kedua negara tersebut. Sementara menurut Fleming (1996) dalam studi longitudinalnya tentang sikap mahasiswa di Irlandia terhadap proses kepemilikan bisnis, mengemukakan bahwa beberapa kendala yang menghalangi keputusan pemilihan karir sebagai wirausaha di masa depan antara lain kurangnya pengalaman dan kurangnya keuangan.

\section{Dukungan Pemerintah}

UKM mengambil peran penting dalam pertumbuhan ekonomi di suatu negara melalui terciptanya bisnis baru atau perluasan bisnis ke pasar baru. Berdasarkan data statistik menunjukkan bahwa jenis usaha ini mampu memberikan kontribusi signifikan dan menjadi tulang punggung pertumbuhan ekonomi di Malaysia, yaitu berkontribusi sebesar 37\% terhadap PDB tahun 2010. UKM juga diharapkan mampu berkontribusi terhadap PDB negara hingga 40\% pada tahun 2020 (New Sabah Times, 2011). Hal demikian juga terjadi di Indonesia. Data Kementerian Koperasi dan UKM RI, Sensus Ekonomi dari Badan Pusat Statistika pada 2016 menunjukkan bahwa UKM menyumbang sebesar $60,34 \%$ dari total PDB Nasional. Menurut Fakhrul dan Wan Norhayate (2011), UKM secara luas dianggap sebagai alat penting untuk menyelesaikan permasalahan ekonomi negara, diantaranya adalah pengangguran dan stagnasi industri. Oleh karena itu, peran pemerintah dalam pengembangan UKM harus semakin meningkat.

Gnyawali dan Fogel (1994) mengemukakan bahwa pemerintah dapat meningkatkan kewirausahaan melalui program bantuan seperti penawaran pajak dan insentif lainnya, meminimalkan peraturan dan regulasi, serta menyediakan lingkungan wirausaha yang kondusif. Fogel (2001) mendukung dengan studinya tentang pengembangan kewirausahan di Hongaria, yang menyimpulkan bahwa pemerintah 
harus menawarkan insentif pajak dan program khusus UKM lainnya. Demikian pula, penelitian Moy, et. al (2001) tentang persepsi mahasiswa Thailand dan Hongkong untuk menjadi wirausaha ada empat kategori bantuan pemerintah, diantaranya dukungan keuangan, bisnis ramah lingkungan, dukungan teknis dan perluasan pasar baru, serta program pendidikan dan tarif.

\section{Faktor Demografis}

Perbedaan gender memang banyak terjadi dalam kecenderungan berwirausaha atau perilaku kewirausahaan. Penelitian Dunn (2004), Veciana, et. al (2005), dan Sandhu, et. al. (2011) mengungkapkan bahwa laki-laki lebih cenderung melakukan bisnis dibanding perempuan. Selain jenis kelamin, ditemukan bahwa urutan kelahiran dalam keluarga juga mempengaruhi perilaku kewirausahaan seseorang. Robinson dan Hunt (1992) menemukan bahwa anak sulung dalam keluarga secara signifikan berhubungan dengan kecenderungan untuk menjadi wirausaha. Variabel menarik lainnya yang digunakan untuk dikaitkan dengan perilaku kewirausahaan seseorang adalah pengalaman wirausaha. Penelitian Lena dan Wong (2003) dan Mukhtar, et. al. (1999) menyebutkan bahwa pengalaman kerja individu sebelumnya secara positif atau negatif mempengaruhi kenerja kewirausahaan.

\section{METODE PENELITIAN}

Penelitian ini menggunakan metode kuantitatif. Pengumpulan data primer menggunakan kuesioner secara daring dengan membagikan link google form kepada masing-masing ketua kelas yang kemudian dibagikan ulang ke mahasiswa lain dalam satu kelas tersebut. Responden penelitian ini merupakan mahasiswa Semester 6 Universitas PGRI Madiun Tahun ajaran 2018/2019 yang sudah menempuh mata kuliah Kewirausahaan dan sedang menjalani jurusan konsentrasi. Hasil kuesioner yang kembali sebanyak 67,36\% tingkat respons, yaitu 227 dari 337 mahasiswa aktif semester enam. Survei ini dilakukan dengan memilih sampel secara acak (random sampling). Mahasiswa yang dipilih adalah mahasiswa semester atas yang sudah hendak menyusun tugas akhir karena menurut Super (1990) mereka dianggap sudah memiliki pemahaman yang lebih baik tentang karir dan masa depan. Pernyataan ini dikuatkan oleh Ooi (2008) 
bahwa mahasiswa tersebut akan berada pada posisi yang lebih baik dalam mengencangkan tujuan kejuruan berdasarkan minat jurusan yang sudah mereka pilih.

Kuesioner ini dikelola sendiri dengan mengadaptasi dari penelitian sebelumnya oleh ooi dan Ahmad (2012). Kuesioner ini berdasarkan skala likert dengan lima pilihan tingkatan, yaitu: sangat tidak setuju, tidak setuju, netral, setuju, dan sangat setuju. Variable yang diuji antara lain adalah niat menjadi wirausaha, motivasi untuk memulai bisnis, tantangan yang dihadapi, dan dukungan pemerintah terhadap pelaku wirausaha. Selain itu, data pribadi responden meliputi jenis kelamin, usia, konsentrasi jurusan, pengalaman kerja, latar belakang pekerjaan orang tua, urutan kelahiran dalam keluarga, dan lain-lain yang berkaitan dengan minat responden untuk berwirausaha turut dimasukkan dalam penelitian ini. Data hasil survei dalam penelitian ini diolah dengan menggunakan software SPSS. Analisis data yang digunakan adalah deskriptif.

\section{HASIL DAN PEMBAHASAN}

Data profil responden dalam penelitian ini menyatakan bahwa mayoritas responden adalah perempuan (78\%) dibandingkan dengan laki-laki (22\%). Kondisi demikian mirip dengan populasi mahasiswa di Universitas PGRI Madiun dimana memang didominasi oleh perempuan. Usia responden berkisar 20-24 tahun yaitu sebanyak 95,2\% dan yang merupakan anak pertama dalam keluarga sebesar 37,9\%. Mayoritas responden berasal dari rural area atau pedesaan, yaitu 73,1\%. Dari ketiga jurusan konsentrasi yang disediakan oleh kampus, mahasiswa terbanyak berasal dari konsentrasi pemasaran, yaitu 54,2\% kemudian konsentrasi sumber daya manusia sebesar 37,9\% dan sisanya berasal dari konsentrasi keuangan. Sebanyak 63,4\% mahasiswa tidak memiliki pengalaman kerja.

Ketika mahasiswa diminta untuk menyebutkan latar belakang pekerjaan orang tua, hasil survei yang didapat adalah 52,4\% ayah mereka bekerja, dan 37,4\% ibu mereka tdak bekerja. Sementara sebanyak $56,8 \%$ percaya bahwa karir mereka tidak dipengaruhi oleh orang tua. Berikut data selengkapnya pada Tabel 1. 
Tabel 1. Latar Belakang Responden

\begin{tabular}{|c|c|c|}
\hline Karakteristik Responden & Frekuensi & Persentase $(\%)$ \\
\hline \multicolumn{3}{|l|}{ Jenis Kelamin } \\
\hline Laki-laki & 50 & 22 \\
\hline Perempuan & 177 & 78 \\
\hline \multicolumn{3}{|l|}{ Usia } \\
\hline$<20$ tahun & 7 & 3,1 \\
\hline 20-24 tahun & 216 & 95,2 \\
\hline 25-29 tahun & 4 & 1,7 \\
\hline$>29$ tahun & 0 & 0 \\
\hline \multicolumn{3}{|l|}{ Posisi dalam Keluarga } \\
\hline Anak Tunggal & 40 & 17,6 \\
\hline Anak Pertama & 85 & 37,9 \\
\hline Anak Kedua & 55 & 24,2 \\
\hline Anak Terakhir & 41 & 18,1 \\
\hline Lain-lain & 6 & 2,2 \\
\hline \multicolumn{3}{|l|}{ Asal Daerah } \\
\hline Rural Area (Pedesaan) & 166 & 73,1 \\
\hline Urban Area (Perkotaan) & 61 & 26,9 \\
\hline \multicolumn{3}{|l|}{ Konsentrasi Jurusan } \\
\hline Sumber Daya Manusia & 54,2 & 123 \\
\hline Pemasaran & 37,9 & 86 \\
\hline Keuangan & 7,9 & 18 \\
\hline \multicolumn{3}{|l|}{ Pengalaman Kerja } \\
\hline $\mathrm{Ya}$ & 144 & 63,4 \\
\hline Tidak & 83 & 36,6 \\
\hline \multicolumn{3}{|l|}{ Masa Kerja } \\
\hline$<1$ Tahun & 98 & 43,2 \\
\hline 2-5 Tahun & 49 & 21,6 \\
\hline Lain-lain & 80 & 35,2 \\
\hline \multicolumn{3}{|l|}{ Bidang Kerja } \\
\hline Sektor Pemerintahan & 13 & 5,7 \\
\hline Sektor Pribadi & 43 & 18,9 \\
\hline Bisnis Relatif & 60 & 26,4 \\
\hline Lain-lain & 111 & 49 \\
\hline \multicolumn{3}{|l|}{ Status Pekerjaan Ayah } \\
\hline Bekerja & 119 & 52,4 \\
\hline Wirausaha & 48 & 21,1 \\
\hline Disela-sela Pekerjaan & 8 & 3,5 \\
\hline Tidak Bekerja & 8 & 3,5 \\
\hline Pensiunan & 17 & 7,5 \\
\hline Lain-lain & 27 & 12 \\
\hline \multicolumn{3}{|l|}{ Status Pekerjaan Ibu } \\
\hline Bekerja & 58 & 25,6 \\
\hline Wirausaha & 52 & 22,9 \\
\hline Disela-sela Pekerjaan & 8 & 3,5 \\
\hline Tidak Bekerja & 85 & 37,4 \\
\hline Pensiunan & 0 & 0 \\
\hline Lain-lain & 24 & 10,6 \\
\hline
\end{tabular}




\begin{tabular}{|l|c|c|}
\hline Pengaruh Karir dari Orang Tua & 98 & 43,2 \\
Ya & 129 & 56,8 \\
\hline Tidak & \\
\hline
\end{tabular}

Sumber: Data Primer Kuesioner, 2021

Ghozali (2009) menyatakan bahwa uji validitas digunakan untuk mengukur sah atau valid tidaknya kuesioner. Kuesioner dikatakan valid jika pertanyaan pada kuesioner mampu untuk mengungkapkan sesuatu yang akan diukur oleh kuesioner. Berikut adalah daftar pertanyaan setiap faktor disertai hasil uji validitas disajikan dalam Tabel 2.

Tabel 2. Tabel Uji Validitas

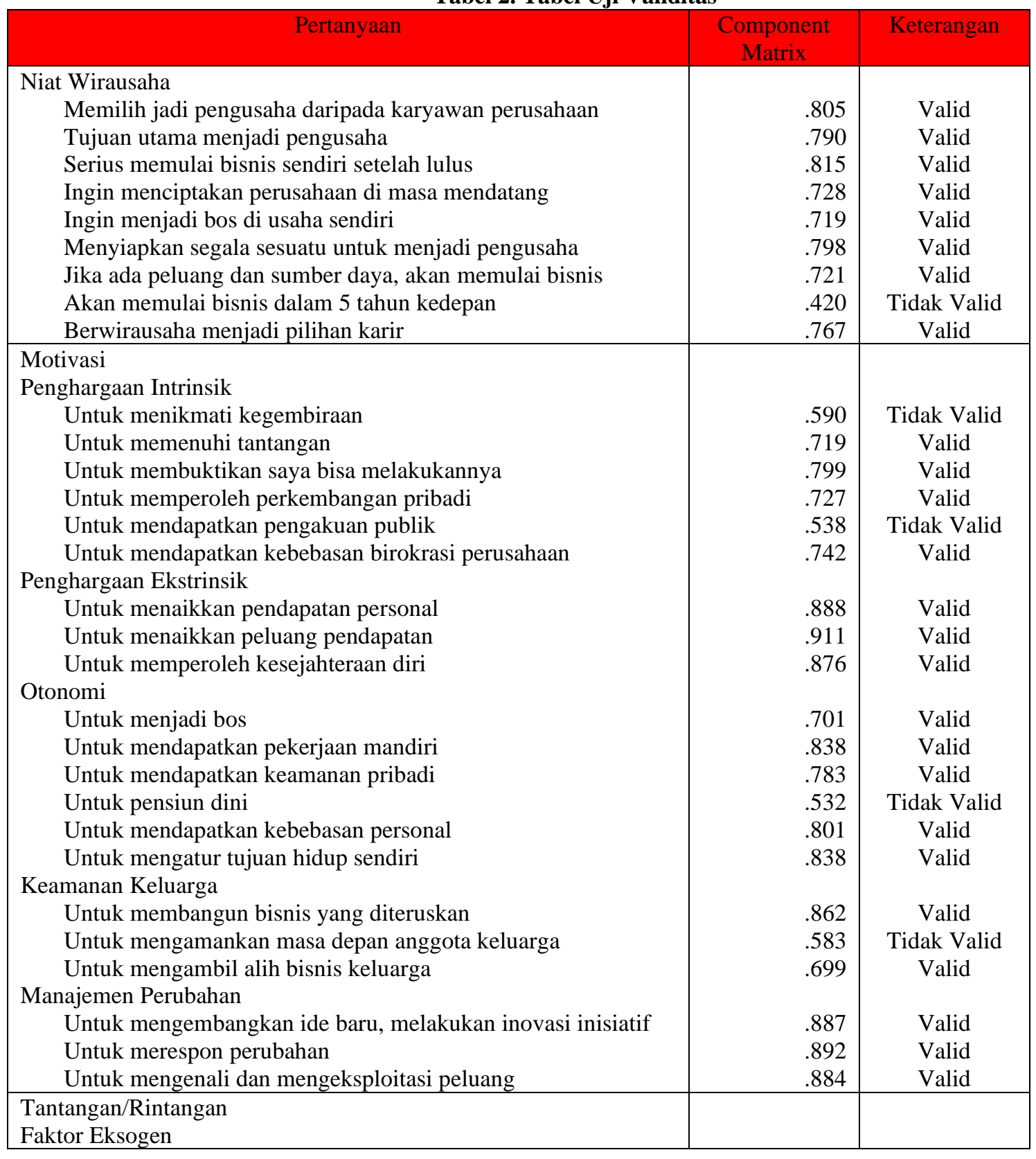

145 | C A P I T A L, V O L U ME 4, NOMOR 2, MARET 2021 


\begin{tabular}{|l|r|c|}
\hline Suku bunga tinggi & .631 & Valid \\
Biaya tenaga kerja tinggi & .704 & Valid \\
Peraturan pemerintahan yang ketat & .850 & Valid \\
Pasar tenaga kerja yang ketat & .844 & Valid \\
Pajak tinggi & .842 & Valid \\
Kurang dukungan pemerintah & .744 & Valid \\
Kompetitor yang kuat & .701 & Valid \\
Faktor Eksogen - Personal & & \\
Stres & .757 & Valid \\
Takut gagal & .794 & Valid \\
Kurang kemampuan bisnis & .849 & Valid \\
Kurang perencanaan dan pandangan jauh ke depan & .867 & Valid \\
Risiko yang berlebihan & .869 & Valid \\
Faktor Eksogen - Keuangan dan Operasional & & \\
Beban operasional tinggi & .803 & Valid \\
Kurangnya modal kerja / investasi & .879 & Valid \\
Pendanaan & .882 & Valid \\
Kurangnya pemasok yang bagus & .838 & Valid \\
\hline Dukungan Pemerintah & & \\
Dukungan pemerintah terhadap inovasi & .724 & Valid \\
Menyediakan pelatihan dan pengembangan melalui seminar & .859 & Valid \\
Menyediakan bimbingan dan keahlian & .858 & Valid \\
Menyediakan asistensi keuangan & .868 & Valid \\
Deregulasi dalam berbagai factor & .841 & Valid \\
Insentif pajak & .731 & Valid \\
\hline
\end{tabular}

Sumber: Olah Data Primer, 2021

Dari 52 butir pertanyaan, ada 5 pertanyaan yang menunjukkan tidak valid. Maka selanjutnya untuk 5 pertanyaan ini tidak dipakai untuk penelitian ini. Sujarweni (2014) menjelaskan bahwa uji reliabilitas dapat dilakukan secara bersama-sama terhadap seluruh butir pertanyaan dalam kuesioner penelitian. Uji reliabilitas dapat dilihat dari nilai Cronbach's Alpha. Jika nilai Cronbach's Alpha > 0,6 maka kuesioner dinyatakan reliabel atau konsisten. Hasil olah data uji reliabilitas disajikan dalam Tabel 3 berikut ini.

Tabel 3 Uji Reliabilitas

\begin{tabular}{|l|r|r|}
\hline & Cronbach's Alpha & N \\
\hline Niat Wirausaha & .885 & 9 \\
\hline Motivasi Penghargaan Intrinsik & .755 & 6 \\
\hline Motivasi Penghargaan Ekstrinsik & .870 & 3 \\
\hline Motivasi Otonomi & .821 & 6 \\
\hline Motivasi Keamanan Keluarga & .531 & 3 \\
\hline Motivasi Manajemen Perubahan & .865 & 3 \\
\hline Tantangan Eksogen & .878 & 7 \\
\hline Tantangan Eksogen Personal & .881 & 5 \\
\hline Tantangan Keuangan \& Operasional & .872 & 4 \\
\hline Dukungan Pemerintah & .897 & 6 \\
\hline
\end{tabular}

Sumber: Olah Data Primer, 2021 
Dari Tabel 3 di atas terdapat satu faktor dengan nilai Cronbach's Alpha $<0,6$ yaitu pada Motivasi Keamanan Keluarga. Maka faktor tersebut dianggap kurang konsisten dalam kuesioner penelitian ini.

Responden diminta untuk menilai niat mereka untuk menjadi wirausaha. Skala yang digunakan adalah skala likert lima poin dengan angka 5 sangat setuju dan angka 1 sangat tidak setuju. Hasil uji statistik deskriptif untuk setiap faktor dengan beberapa bagian pertanyaan menunjukkan hasil yang cukup baik secara keseluruhan. Tabel 4 berikut ini menunjukkan bahwa faktor motivasi masih lebih tinggi daripada faktor tantangan yang dihadapi oleh mahasiswa.

Tabel 4 Statistik Deskriptif

\begin{tabular}{|l|r|r|r|}
\hline & Mean & Std. Deviasi & \multicolumn{1}{l|}{ N } \\
\hline Niat Wirausaha & 3.7753 & .71502 & 227 \\
\hline Motivasi Penghargaan Intrinsik & 3.6167 & .66405 & 227 \\
\hline Motivasi Penghargaan Ekstrinsik & 4.4141 & .73194 & 227 \\
\hline Motivasi Otonomi & 3.8502 & .75524 & 227 \\
\hline Motivasi Keamanan Keluarga & 3.5330 & .83746 & 227 \\
\hline Motivasi Manajemen Perubahan & 4.2379 & .87024 & 227 \\
\hline Tantangan Eksogen & 3.1586 & .87818 & 227 \\
\hline Tantangan Eksogen Personal & 2.9912 & 1.02617 & 227 \\
\hline Tantangan Keuangan \& Operasional & 3.3744 & .91005 & 227 \\
\hline Dukungan Pemerintah Sumber: Olah Data Primer, 2021 & 3.6520 & .77433 & 227 \\
\hline \multicolumn{2}{|r}{}
\end{tabular}

Berdasarkan Tabel 4 di atas faktor dengan nilai rata-rata tertinggi adalah pada faktor Motivasi Penghargaan Ekstrinsik dengan nilai mean 4,4 dan standar deviasi 0,73. Sementara faktor dengan nilai rata-rata terendah adalah Tantangan Eksogen Personal dimana nilai mean hanya 2,99 dan standar deviasi 0,77 . Sementara hasil hubungan antar faktor juga saling berkorelasi positif satu sama lain dengan nilai signifikansi $<0,1$.

\section{E. SIMPULAN}

Hasil penelitian ini menyimpulkan bahwa mahasiswa Universitas PGRI Madiun memiliki niat yang cukup tinggi untuk menjadi wirausaha. Motivasi terbesarnya adalah untuk menaikkan peluang pendapatan. Sementara yang dianggap tantangan terbesar untuk menjadi wirausaha adalah pendanaan. Maka sejalan dengan dukungan pemerintah yang sangat dibutuhkan adalah menyediakan asistensi pendanaan. 
Kewirausahaan semakin diakui berperan penting dalam pertumbuhan perekonomian Indonesia. Penelitian ini sebagai gambaran bagi universitas dan pemerintah agar lebih menumbuhkan, mengembangkan, dan melatih jiwa kewirausahaan mahasiswa sehingga lebih proaktif dan mampu memulai bisnis setelah lulus kuliah. Upaya ini mampu dicapai dengan cara menyediakan pendidikan kewirausahaan yang bermutu dan komprehensif, serta dapat membekali mahasiswa dengan pengetahuan dan keterampilan kewirausahaan.

\section{DAFTAR PUSTAKA}

Astrachan, J.H., \& Shanker, M.C. (2003). Family Business Contribution to the US Economy: A Close Look. Family Business Review. 16(3), 211-220.

Badan Pusat Statistik. (2020). [REVISI per 23/11/2020] Agustus 2020: Tingkat Pengangguran Terbuka (TPT) sebesar 7,07 persen. Tersedia di https://www.bps.go.id/pressrelease/2020/11/05/1673/agustus-2020--tingkatpengangguran-terbuka--tpt--sebesar-7-07persen.html\#: :text=Tingkat\%20pengangguran\%20terbuka\%20(TPT)\%20Agustus, juta\%20orang\%20dari\%20Agustus\%202019 diakses pada 20 Desember 2020

Fleming, P. (1996) Entrepreneurship Education in Ireland: A Longitudinal Study. Academy of Entrepreneurship Journal. 2(1), 94-118.

Ghozali, Imam. (2009). Aplikasi Analisis Multivariate dengan Program SPSS. Semarang: Badan Penerbit Universitas Diponegoro.

Gnyawali, D. R., \& Fogel, D.S. (1994). Environments for Entrepreneurship Development: Key Dimensions and Research Implications. Entrepreneurship Theory and Practice. 18(4), 43-62.

Kompas. (2012). Peran UMKM dalam Perekonomian Indonesia. Tersedia di https://www.kompas.com/skola/read/2019/12/20/120000469/peran-umkm-dalamperekonomianindonesia?page $=$ all\#: :text=Berikut\%20ini\%20sumbangan\%20UMKM\%20terhada p\%20perekonomian\%20Indonesia\%3A\&text=UMKM\%20menyediakan\%20hingga \%2099\%20persen,17\%20persen\%20dari\%20total\%20ekspor diakses pada 2 Januari 2021

Kao, W. Y. (1995) Why Entrepreneurship Could be Taught and Should be Taught Including an Introduction to a Model for Entrepreneurship Education. Journal of Small Business and Entrepreneurship. 12(4), 97-99

Kuesioner Motivasi dan Tantangan menjadi Wirausaha (Studi Kuantitatif pada Mahasiswa UNIPMA Madiun) tersedia di https://docs.google.com/forms/d/101g9CoVJ4_oz3SPILcr4- 
AYkvo6_DbKJ19NVCEXCSc/edit?usp=forms_home\&ths=true diakses 10 Januari 2021

Kuratko, D.F., \& Hodgetts, R. M. (2007) Entrepreneurship: Theory, Process and Practice. 7th Edition. Ohio, US: Thomson Learning.

Ooi, Yeng Keat, \& Ahmad, Shuhymee. (20012). A Study among University Students in Business Start-Ups in Malaysia: Motivations and Obstacles to Become Entrepreneurs. International Journal of Business and Social Science. Vol. 3 No.19.

Sujarweni, Wiratna V. (2014). SPSS untuk Penelitian. Yogyakarta: Pustaka Baru Press. 